\title{
Influence of Cave Size and Presence of Bat Guano on Ant Visitation
}

by

Wesley Dáttilo ${ }^{1^{*}}$, Ricardo E. Vicente ${ }^{1}$, Rafael V. Nunes ${ }^{2} \&$ Rodrigo M. Feitosa $^{3}$

\section{ABSTRACT}

This is the first study which evaluated the influence of cave size and presence of bat guano in ant visitation in Brazilian caves. We provide a list of the ants associated with 27 caves in northeastern Brazil, an area situated in the transition between Cerrado (Brazilian savanna) and Amazon Domain. The study was conducted between January and August 2010. We recorded 24 ant species inserted into 12 genera, 10 tribes, and six subfamilies. The size of the cave and the presence of guano did not influence the richness of ants, and most of the caves had single species. Camponotus atriceps was the species with the larger distribution, being collected in five caves. In addition, we discuss geographic distribution of records and possible ecological roles of ants in cave environments.

Key Words: Biospeleology, Cavernicolous; Competition; Invertebrates.

\section{INTRODUCTION}

Despite the fact that Brazil has one of the most valuable and diversified speleological patrimonies in the world (Santos et al. 2002), cave fauna inventories are rare (Dessen et al. 1980). Until 1994, there were 76 known vertebrate species and 537 invertebrate species inhabiting Brazilian caves (Pinto-da-Rocha 1995). These organisms can be classified into three categories: (1) trogloxenes, which spend part of their life into the cave but return to the exterior to finish their life cycle; (2) troglophiles, which have established populations and can finish their life cycle both in the exterior and interior of

\footnotetext{
${ }^{1}$ Departament of Ecology and Botany, Insect-Plant Interactions Lab., Universidade Federal de Mato Grosso, 78060-900. Cuiabá, Mato Grosso, Brazil.

${ }^{2}$ Departament of Biology and Zoology, Universidade Federal de Mato Grosso, 78060-900. Cuiabá, MT, Brazil.

${ }^{3}$ Department of Entomology, Museu de Zoologia da Universidade de São Paulo, 04263-000, São Paulo, SP, Brazil.

*Email:wdattilo@hotmail.com
} 
the cave, and (3) troglobites, which are restricted to the cave environment and only finish their life cycle inside the cave (Holsinger \& Culver 1988).

One of the most important features of caves is the absence of light or low light incidence and a high environmental stability (Culver 1982, Howarth 1983). Therefore, with the absence of photosynthetic organisms, invertebrates are responsible for major richness and abundance in almost all cave ecosystems. Troglophiles can be considered the most frequent kind of organism in cave habitats (Trajano 1987, Trajano \& Gnaspini-Netto 1991, Ferreira \& Horta 2001).

Although ants are frequently cited inhabiting caves, there are no records of troglobite ant species in these habitats. In most of the records, ant fauna are found far from the cave entrance. In addition, ant species found in caves are usually common in other ecosystems and have wide geographic distribution. The presence of ants has been considered by author as accidental in most cases (Wilso 1962, Tinaut \& López 2001, Dáttilo et al. 2010). Some authors attribute the ant entry in caves to foraging, being associated with bat feces (guano) (Ferreira \& Martins 1999a, 1999b, Ferreira etal. 2000, Roncin $\&$ Deharveng 2003, Santana et al. 2010). The ants collect fresh guano, and carry it back to the nest where it is used as food (Moulds 2006).

These statements lead us to suppose that in the caves where guano is present, the ant visitation is higher than in the caves that this resource is not found. Furthermore, as the species-area relationship is one of the more established patterns in ecology (MacArthur \& Wilson 1967) and has been evidenced in cave environments (Culver et al. 2004), we also suppose that the number of species of ants will increase as the size of the caves grows. Finally, we provide a species list of ants associated with different caves in the southern of Maranhão State, northeastern Brazil and we discuss geographic distribution of records and possible ecological roles of ants in cave environments.

\section{MATERIAL AND METHODS}

\section{Study area}

We developed this work in 27 caves in the municipality of Estreito, located in the marker between states of Maranhão and Tocantins in January and August 2010. This region is inserted into a transition zone between "Cerrado" (Brazilian savanna) and Amazon biomes at the Tocantins river basin. The 
physiognomy surrounding the caves can be classified as Cerrado sensu stricto. For detailed descriptions of this classification see the classic studies of Eiten (1972) and Ribeiro \& Walter (1998). The mean annual temperature is $26.1^{\circ} \mathrm{C}$, with mean precipitation of $1718 \mathrm{~mm}$ fitting in a tropical rain pattern where the rainy period corresponds to $80 \%$ of annual precipitation (Ceste 2004). The class of soil that predominates in the region is Neosoil, Quartzarenic, in flat topography and sandy sediment cover and alterations in rocks of quartz and sandstone (Reatto et al. 1998).

Table 1. Number, geographic coordinates, length $(\mathrm{m})$, height $(\mathrm{m})$, presence $(\mathrm{P})$ or absence $(\mathrm{A})$ of guano and number of installed pitfalls in studied caves in municipality of Estreito, Maranhão, Brazil.

\begin{tabular}{|c|c|c|c|c|c|}
\hline Cave & Coordinates & Length $(\mathrm{m})$ & Height (m) & Guano & $\mathrm{n}^{\circ}$ of pitfalls \\
\hline 1 & $6^{\circ} 03^{\prime} 57^{\prime \prime S} .47^{\circ} 30^{\prime} 06^{\prime \prime} \mathrm{W}$ & 53 & 18 & (A) & 2 \\
\hline 2 & & 3.3 & 1.8 & (A) & 2 \\
\hline 3 & $6^{\circ} 43^{\prime} 17^{\prime \prime} \mathrm{S}, 47^{\circ} 28^{\prime} 07^{\prime \prime} \mathrm{W}$ & 6 & 2.5 & (A) & 1 \\
\hline 4 & $6^{\circ} 51^{\prime} 45^{\prime \prime} \mathrm{S}, 47^{\circ} 28^{\prime} 07^{\prime \prime} \mathrm{W}$ & 6.2 & 3.5 & (P) & 1 \\
\hline $\begin{array}{l}4 \\
5\end{array}$ & $6^{\circ} 50^{\prime} 45^{\prime \prime} \mathrm{S}, 47^{\circ} 32^{\prime} 00^{\prime \prime} \mathrm{W}$ & 6.2 & 1.7 & (A) & 2 \\
\hline 5 & $6^{\circ} 51^{\prime} 45^{\prime \prime} \mathrm{S}, 47^{\circ} 32^{\prime} 00^{\prime \prime} \mathrm{W}$ & 6.2 & 2 & $(\mathrm{P})$ & 2 \\
\hline 6 & $6^{\circ} 32^{\prime} 09^{\prime \prime} \mathrm{S}, 47^{\circ} 28^{\prime} 46^{\prime \prime} \mathrm{W}$ & 7 & 1.3 & (A) & 2 \\
\hline 7 & $6^{\circ} 51^{\prime} 48^{\prime \prime} \mathrm{S}, 47^{\circ} 30^{\prime} 58^{\prime \prime} \mathrm{W}$ & 7 & 1.6 & (A) & 2 \\
\hline 8 & $6^{\circ} 51^{\prime} 48^{\prime \prime} \mathrm{S}, 47^{\circ} 30^{\prime} 50^{\prime \prime} \mathrm{W}$ & 7 & 1 & (A) & 2 \\
\hline 9 & $6^{\circ} 51^{\prime} 36^{\prime \prime}$ S, $47^{\circ} 31^{\prime} 08^{\prime \prime} \mathrm{W}$ & 7.4 & 1.4 & (A) & 1 \\
\hline 10 & $6^{\circ} 52^{\prime} 36^{\prime \prime} \mathrm{S}, 47^{\circ} 31^{\prime} 08^{\prime \prime} \mathrm{W}$ & 7.4 & 1 & (A) & 2 \\
\hline 11 & & 7.4 & 4 & (A) & 2 \\
\hline 12 & $6^{\circ} 52^{\prime} 20^{\prime \prime} \mathrm{S}, 47^{\circ} 29^{\prime} 53^{\prime \prime} \mathrm{W}$ & 8 & 1.5 & (P) & 2 \\
\hline 13 & 6.53'28" S, $47^{\circ} 29^{\prime} 53^{\prime \prime} \mathrm{W}$ & 8 & 1.) & $(\mathrm{P})$ & 2 \\
\hline 14 & $\begin{array}{l}6^{\circ} 53^{\prime} 28^{\prime} \mathrm{S}, 47^{\circ} 29^{\prime} 53^{\prime \prime W} \\
6^{\circ} 44^{\prime} 23^{\prime \prime} \mathrm{S}, 47^{\circ} 23^{\prime} 20^{\prime \prime}\end{array}$ & & 1 & (P) & 2 \\
\hline 15 & $\begin{array}{l}6^{\circ} 44^{\prime} 23^{\prime \prime} \text { S, } 47^{\circ} 23^{\prime} 20^{\prime \prime} \mathrm{W} \\
6^{\circ} 48^{\prime} 20^{\prime \prime} \text { S. } 47^{\circ} 31^{\prime} 12^{\prime \prime} \mathrm{W}\end{array}$ & $\begin{array}{l}8 \\
9\end{array}$ & 1.5 & (P) & 2 \\
\hline 16 & & 9 & 1.5 & (A) & 2 \\
\hline 17 & $6^{\circ} 42^{\prime} 22^{\prime \prime} \mathrm{S}, 47^{\circ} 29^{\prime} 43^{\prime \prime} \mathrm{W}$ & 10.3 & 1 & (P) & 2 \\
\hline 18 & $6^{\circ} 55^{\prime} 52^{\prime \prime} \mathrm{S}, 47^{\circ} 22^{\prime} 50^{\prime \prime} \mathrm{W}$ & 11.6 & 1.5 & (A) & 2 \\
\hline $\begin{array}{l}18 \\
19\end{array}$ & $6^{\circ} 51^{\prime} 45^{\prime \prime} \mathrm{S}, 47^{\circ} 27^{\prime} 48^{\prime \prime} \mathrm{W}$ & 15 & 1.5 & (A) & 3 \\
\hline 19 & $6^{\circ} 49^{\prime} 20^{\prime \prime} \mathrm{S}, 47^{\circ} 32^{\prime} 11^{\prime \prime} \mathrm{W}$ & 16 & 1 & (P) & 3 \\
\hline 20 & $6^{\circ} 22^{\prime} 12^{\prime \prime} \mathrm{S}, 47^{\circ} 32^{\prime} 31^{\prime \prime} \mathrm{W}$ & 17 & 2 & (A) & 3 \\
\hline 21 & $6^{\circ} 42^{\prime} 17^{\prime \prime} \mathrm{S}, 47^{\circ} 28^{\prime} 07^{\prime \prime} \mathrm{W}$ & 17.5 & 2 & (A) & 3 \\
\hline 22 & $6^{\circ} 41^{\prime} 18^{\prime \prime} \mathrm{S}, 47^{\circ} 27^{\prime} 06^{\prime \prime} \mathrm{W}$ & 19.5 & 1 & (P) & 4 \\
\hline 23 & $6^{\circ} 42^{\prime} 17^{\prime \prime}$ S, $47^{\circ} 29^{\prime} 07^{\prime \prime} \mathrm{W}$ & 19.5 & 2.5 & (P) & 4 \\
\hline 24 & $6^{\circ} 55^{\prime} 31^{\prime \prime} \mathrm{S}, 47^{\circ} 30^{\prime} 58^{\prime \prime} \mathrm{W}$ & 20 & 1.5 & $(P)$ & 4 \\
\hline 25 & $6^{\circ} 53^{\prime} 31^{\prime \prime} \mathrm{S}, 47^{\circ} 29^{\prime} 58^{\prime \prime} \mathrm{W}$ & 20 & 17 & (A) & $\begin{array}{l}4 \\
4\end{array}$ \\
\hline 26 & $\begin{array}{l}053310,4 / 4958 \mathrm{~W} \\
6053^{\prime} 31^{\prime \prime} 47^{\circ} 29^{\prime} 58^{\prime \prime} \mathrm{W}\end{array}$ & 20 & 1.7 & (P) & 4 \\
\hline 27 & 60331 J, 4/.2938 W & 20 & 2 & $(\mathrm{P})$ & 4 \\
\hline & $64046 \mathrm{~S}, 472924 \mathrm{~W}$ & 21.3 & 3.3 & (A) & 4 \\
\hline
\end{tabular}




\section{Data collection and analysis}

We used two kinds of sampling: pitfall traps and manual collection. Pitfalls were made with $500 \mathrm{ml}$ plastic cups containing a $150 \mathrm{ml}$ solution composed of $70 \%$ Alcohol and detergent. The pitfalls remained in the caves for 48 hours. The number of installed pitfalls ranged among caves as a function of the size of cave (Table 1). Manual collections were made in the installation and removal of pitfall traps. The ants collected in all caves were identified through comparisons with the available collection of the Museu deZoologia of Universidade de São Paulo, Brazil (MZSP). All collected ants were deposited in the Setor de Entomologia of Coleção Zoológica of Universidade Federal de Mato Grosso, Brazil (CEMT).

To assess whether the presence of bat guano influenced the number of ants species we noted the data for bat guano presence/absence of each cave. For this, we used non-parametric Mann-Whitney $U$ test. To evaluate if the cave area influenced the number of ants species we measures on each cave: major length, also called development and major height (Table 1). Spearman correlation was performed to verify if there is relation within richness and size of the cave. All tests were made using SYSTAT 8.0 (Wilkinson 1998).

\section{RESULTS}

We found 24 ant species inserted into 12 genera, 10 tribes and six subfamilies. Myrmicinae was the subfamily that had most taxa recorded with 14 species. The most abundant genera were Camponotus and Pheidole, represented by five and six species respectively. Additionally, $81.4 \%$ of caves $(n=22)$ had only a single species, and Camponotus atriceps (Smith 1858) was present in five of 27 sampled caves (Table 2).

Twelve of the 27 caves had guano. The presence of guano did not influence ant richness (Mann-Whitney, $\mathrm{z}(\mathrm{u})=1.073, \mathrm{P}=0.283$ ). The average size (length $\mathrm{x}$ height) of the caves was $16.4 \mathrm{~m}^{2} \pm 13.2$; however, ant richness was not related with the cave size (Spearman's Correlation, $\mathrm{rs}=-0.191, \mathrm{t}=-0.976$, $\mathrm{P}=0.338$ ). Therefore, neither guano or cave size are modulating resources of ant richness in these environments. 
Table 2. Taxonomic classification, author, year, number of cave of occurrence, geographical distribution (Geo. Dist.) and respective references of ant fauna collected in municipality of Estreito, Maranhão State, northeastern Brazil in January and August 2010. *Geographical distributions was determined only for ants identified to species level. Geographic distribution: (NEO) Neotropical, (SOU) South America, (AM) American Continent. References: (1) Lapola et al. 2003, (2) Giraud et al. 2000, (3) Brandão 1991, (4) Solis et al. 2010, (5) Dáttilo et al. 2010, (6) Naves 1985, (7) Maes \& Mackay 1993.

\begin{tabular}{|c|c|c|c|}
\hline Taxon, author, year & Cave & Geo.Dist* & References \\
\hline \multicolumn{4}{|l|}{ SUBFAMILY DOLICHODERINAE } \\
\hline \multicolumn{4}{|l|}{ TRIBE DOLICHODERINI } \\
\hline \multicolumn{4}{|l|}{ Dolichoderus Lund, 1831} \\
\hline Dolichoderus sp.1 & 23 & - & - \\
\hline \multicolumn{4}{|l|}{ SUBFAMILY ECITONINAE } \\
\hline \multicolumn{4}{|l|}{ TRIBE ECITONINI } \\
\hline \multicolumn{4}{|l|}{ Eciton Latreille, 1804} \\
\hline Eciton sp.1 & 7 & - & - \\
\hline \multicolumn{4}{|l|}{ SUBFAMILY ECTATOMMINAE } \\
\hline \multicolumn{4}{|l|}{ TRIBE ECTATOMMINI } \\
\hline Ectatomma brunneum Smith, 1858 & 22 & $\mathrm{NEO}$ & 1 \\
\hline Gnamptogenys striatula Mayr, 1884 & 9 & $\mathrm{NEO}$ & 2 \\
\hline \multicolumn{4}{|l|}{ SUBFAMILY FORMICINAE } \\
\hline \multicolumn{4}{|l|}{ TRIBE CAMPONOTINI } \\
\hline \multicolumn{4}{|l|}{ Camponotus Mayr, 1866} \\
\hline Camponotus sp.1 & 5 & - & - \\
\hline Camponotus sp.2 & 12 & - & - \\
\hline Camponotus sp.3 & 9 & - & - \\
\hline Camponotus atriceps Mayr, 1862 & $4,11,14,15,26$ & $\mathrm{NEO}$ & 3 \\
\hline Camponotus vittatus Forel, 1904 & 10 & $\mathrm{NEO}$ & 4 \\
\hline \multicolumn{4}{|l|}{ SUBFAMILY MYRMICINAE } \\
\hline \multicolumn{4}{|l|}{ TRIBE ATTINI } \\
\hline \multicolumn{4}{|l|}{ Acromyrmex Mayr, 1865} \\
\hline Acromyrmex hystrix (Latreille, 1802) & 27 & SOU & 5 \\
\hline Acromyrmex sp.1 & 13 & - & - \\
\hline \multicolumn{4}{|l|}{ TRIBE CEPHALOTINI } \\
\hline Cephalotes atratus (Linnaeus, 1758) & 16,23 & $\mathrm{NEO}$ & 3 \\
\hline
\end{tabular}


Table 2 (Continued). Taxonomic classification, author, year, number of cave of occurrence, geographical distribution (Geo. Dist.) and respective references of ant fauna collected in municipality of Estreito, Maranhão State, northeastern Brazil in January and August 2010. ${ }^{*}$ Geographical distributions was determined only for ants identified to species level. Geographic distribution:(NEO) Neotropical,(SOU) South America, (AM) American Continent. References: (1) Lapola et al. 2003, (2) Giraud et al. 2000, (3) Brandão 1991, (4) Solis et al. 2010, (5) Dáttilo et al. 2010, (6) Naves 1985, (7) Maes \& Mackay 1993.

\begin{tabular}{|c|c|c|c|}
\hline Taxon, author, year & Cave & Geo.Dist* & References \\
\hline \multicolumn{4}{|l|}{ TRIBE CREMATOGASTRINI } \\
\hline \multicolumn{4}{|l|}{ Crematogaster Lund, 1831} \\
\hline Crematogaster sp. 1 & 24 & - & - \\
\hline Crematogaster sp. 2 & 25 & - & - \\
\hline Crematogaster sp. 3 & 13 & - & - \\
\hline \multicolumn{4}{|l|}{ TRIBE PHEIDOLINI } \\
\hline \multicolumn{4}{|l|}{ Pheidole Westwood, 1839} \\
\hline Pheidole sp.1 & 17,21 & - & - \\
\hline Pheidole sp.2 & $8^{*}$ & - & - \\
\hline Pheidole sp.3 & 18 & - & - \\
\hline Pheidole sp.4 & 9 & - & - \\
\hline Pheidole sp.5 & 3 & - & - \\
\hline Pheidole obscurithorax Naves, 1985 & 2,19 & $\mathrm{AM}$ & 6 \\
\hline \multicolumn{4}{|l|}{ TRIBE SOLENOPSIDINI } \\
\hline \multicolumn{4}{|l|}{ Solenopsis Westwood, 1840} \\
\hline Solenopsis sp.1 & 14 & - & - \\
\hline Solenopsis sp.2 & 6,20 & - & - \\
\hline \multicolumn{4}{|l|}{ SUBFAMILY PONERINAE } \\
\hline \multicolumn{4}{|l|}{ TRIBE PONERINI } \\
\hline Odontomachus opaciventris Forel, 1899 & 1,3 & NEO & 7 \\
\hline
\end{tabular}

\section{DISCUSSION}

This is the first study we are aware of where the influence of the size of the cave and the presence of guano on the richness of ants in Brazilian caves was evaluated. Among the ants identified to species level, all have a wide geographic distribution (Table 2) and some of them occur in many kinds of habitats (eg. Pheidole obscurithorax Naves 1985) including urban ones, such as Camponotus vittatus Forel 1904 (Naves 1985, Rodovalho et al. 2005). According to Roncin et al. (2001), the absolute majority of ant species that 
occur inside caves are also found in environments outside the cave. The low number of ant species by cave was already found by other authors in northeastern and southern Brazil (Ferreira \& Horta 2001, Silva et al. 2005, Silva \& Ferreira 2009a, 2009b, Santana et al. 2010). The low number of species in all caves and its lack of relationship with the studied variables (presence of guano and size of the cave), added to wide geographical distributions of found species, emphasizes that the presence of the ants in these caves is accidental, which has been reported several times (Wilson 1962, Tinaut \& López 2001, Dáttilo et al. 2010).

It is noteworthy that the size of the caves in this study are small, though some authors claim that the ants associated with caves can be found only at the entrance of the cave (Ferreira \& Martins 1999a, 1999b, Jordão 2003, Santana et al. 2010, Dáttilo et al. 2010). The species-area relationship is one of the most studied patterns in ecology and used in different systems (MacArthur \& Wilson 1963, Vasconcelos et al. 2006, Lozano-Zambrano et al. 2009), but it does not apply to cave environments. This pattern is based on larger areas that include a high variety and availability of habitats (MacArthur \& Wilson 1967), which should not apply to a cave, since its environmental conditions are constant (Belles 1987) and the resources are usually scarce and unpredictable (Christiansen 1965). Thus, considering only the size of the cave, there isn't an expected increase in species richness of ants in this environment. Additionally, in some cases, the presence of guano may become a limiting factor for the increase in richness and abundance of ants and other invertebrate predators, since many organisms associated with this type of substrate are an important funding source for predators (Gnaspini-Neto 1989, Ferreira \& Martins 1999a, 1999b, Ferreira et al. 2000, Santana et al. 2010). However, in this study the presence of guano didn't influence the richness of ants in the caves. This probably occurred because the caves were small and the accumulation of guano wasn't large enough to support several species of ants. Besides, the competition between the ants would limit the increase in richness of the ants in caves where the guano was present.

The colonization and foraging of many arthropods - including ants - in caves mainly occurs due the favorable and constant environmental conditions inside the cave (Bellés 1987). Despite these favorable conditions, the availability of food resources may negatively affect spatial distribution and 
diversity of ant fauna inside caves (Poulson \& Culver 1969). This may occur because resources in caves are usually scarce and unpredictable, which, over long periods of time, would require morphological and physiological adaptations (Christiansen 1965) that ants do not have. Also, it is probable that high rates of competition due to the scarcity of food resources allow few species to establish inside caves generating the "one ant species for one cave" pattern, related in our study. These are two good reasons why Wilson (1962) considers that ants and other social insects can not be a "real" troglobyte.

The probability of existence of troglobyte ants has generated discussion among researches for a long time, mainly with respect to the absence of gene flow within cave populations (Wilson 1962, Tinaut \& López2001, Roncin \& Deharveng 2003). Some researchers suggest that some ant species are probably troglobytes, such as Leptogenys khammouanensis Roncin \& Deharveng 2003 (Tinaut \& López 2001) and Hypoponera ragusai (Emery 1894) (Roncin \& Deharveng 2003), mainly due to the constant presence of nests of both species in cave interiors and males and females being apterous. However, there is the possibility that these species, being subterranean, simply prefer cryptic habitats, for instance, rodent galleries (Decu et al. 1998, Tinaut \& López 2001). Additionally, the scarcity of resources faced by subterranean ants is a good parallel for us to understand the difficulties that a troglobyte ant would find in this kind of habitat (Deharveng \& Bedos 2000).

Despite the difficulty of categorizing these insects in the three cave fauna categories of organisms, ants may have an important role in cave ecosystems seeing as they may promote the transitions of nutrients between the exterior and interior of cave. Further studies that characterize the ecology and faunistic composition of Brazilian caves are recommended for conservation and management of these unique habitats.

\section{ACKNOWLEDGEMENTS}

We thank Thiago Izzo for careful statistical support and Jéssica Falcão for comments on earlier versions of this manuscript. We also thank CAPES for the masters fellowship to WD and RVN. RMF thanks FAPESP for a PhD. fellowship ( $\mathrm{n}^{\circ}$ 2011/24160-1), and CNPq for a DTI fellowship to REV ( $\mathrm{n}^{\circ}$ 381261/2011-5). 


\section{REFERENCES}

Bellés, X. 1987. Fauna cavernicola i intersticial de La península Ibérica i les illes Balears. Mallorca: Consell Superior d'Investigacions Científiques. 207 pp.

Brandão, C.R.F. 1991. Adendos ao catálogo abreviado das formigas da região neotropical (Hymenoptera: Formicidae). Rev. Bras. Entomol. 35: 319-412.

Ceste, E. 2004. Estudo de Impacto Ambiental-Relatório de Impacto Ambiental do AHE Estreito. Rio de Janeiro: Ceste Consórcio Estreito de Energia. 235 pp.

Christiansen, K.A. 1965. Behavior and form in the evolution of cave Collembola. Evolution 19: 529-533.

Culver, D.C. 1982. Cave Life. Massachusets: Harvard University Press. 189 pp.

Dáttilo, W.F.C., R.E. Vicente, R.V. Nunes, \& M.S.G. Carvalho. 2010. Primeiro registro da quenquém cisco-da-Amazônia Acromyrmex hystrix Latreille, 1802 (Formicidae: Myrmicinae) para o estado do Maranhão, Brasil. EntomoBrasilis 3(3): 92-93.

Decu, V., A. Casale, P.L. Scaramozzino, F. López, \& A. Tinaut. 1998. Hymenoptera. In: C. Juberthie, \& V. Decu eds., Encyclopaedia Biospeologica. Sociétè de Biospéologie, Moulis, French: 1015-1024.

Deharveng, L., \& A. Bedos. 2000. The cave fauna of southeast Asia. Origin, evolution and ecology. In: H. Wilkens, D.C.Culver, \& W.F. Humphreys eds., Ecosystems of the world: subterranean ecosystems. Elsevier Press., Amsterdam, Netherlands: 603-632.

Dessen, E.M.B., V.R. Eston, M.S. Silva, M.T.T. Beck, \& E. Trajano. 1980. Levantamento preliminar da fauna de cavernas de algumas regiões do Brasil. Cienc. Cult. 32(6): 714- 725 .

Eiten, G. 1972. The cerrado vegetation of Brazil. Bot. Rev. 38: 201-341.

Ferreira, R.L., \& R.P. Martins. 1999a. Guano de morcegos: fonte de vida em cavernas. Cien. Hoje. 25(146): 34-40.

Ferreira, R.L., \& R.P. Martins. 1999b. Trophic structure and natural hystory of bat guano invertebrate communities, whith special reference to brazilian caves. Trop. Zool. 12: 231-252.

Ferreira, R.L., R.P.Martins, \&D. Yanega. 2000. Ecology of bat guano arthropod communities in a Brazilian dry cave. Ecotrop. 6: 105-115.

Ferreira, R.L., \& L.C.S.Horta.2001. Natural and human impacts on invertebrate communities in Brazilian caves. Rev. Bras. Biol. 61(1): 7-17.

Giraud, T., R. Blatrix, C. Poteaux, M. Solignac, \& P. Jaisson. 2000. Population structure and mating biology of the polygynous ponerine ant Gnamptogenys striatula in Brazil. Mol. Ecol. 9: 1835-1841.

Gnaspini-Netto, P. 1989. Fauna associated with bat guano deposits from Brazilian caves (a comparison). In: I Congress of Speleology of Budapest. Budapest, Hungary: 52-54.

Holsinger, R. \& D.C. Culver. 1988. The invertebrate cave fauna of Virgínia and a part of eastern Tenessee: zoogeography and ecology. Brimieyana 14: 1-162.

Howarth, F.G. 1983. Ecology of cave arthropods. Annu. Rev. Entomol. 28: 365-389. 
Jordão, F.S. 2003 Levantamento da fauna de invertebrados da Gruta dos Ecos (GO) durante a estação chuvosa. In: XXVII Congresso Brasileiro de Espeleologia. Januária, Brazil: CD-ROOM.

Lapola, D.M., W.F. Antonialli-Júnior, \& E. Gianotti.2003. Arquitetura da formiga neotropical Ectatomma brunneum F. Smith, 1858 (Formicidae, Ponerinae) em ambientes alterados. Rev. Bras. Bioc. 5(2): 177-188.

Maes, J.M., \& W.P. Mackay. 1993. Catalogo de las hormigas (Hymeniptera: Formicidae) de Nicaragua. Rev. Nic. Entomol. 23: 1-46.

Moulds, T.2006. The first Australian record of subterranean guano-collecting ants. Helictite 39(1): 3-4.

Naves, M. 1985. A monograph of the genus Pheidole in Florida (Hymenoptera: Formicidae). Insecta Mundi 1(2): 53-90.

Pinto-Da-Rocha, R. 1995. Sinopse da fauna cavernícola do Brasil (1907-1994). Pap. Avul. Zool. 39: 61-173.

Poulson, T.L., \& D.C. Culver. 1968. Diversity in terrestrial cave communities. Ecol. 50: 153-157.

Reatto, A., J.R. Correia, \& S.T. Spera. 1998. Solos do bioma cerrado: aspectos pedológicos. In: S.M. Sano, \& S.P. Almeida eds., Cerrado: ambiente e flora. Embrapa Cerrados, Brasília, Brazil: 289-556.

Roncin,E.,L.Deharveng, \&A. Bedos. 2001. Cave ants in Southeast Asia.In:XVInternational Symposium of Biospeleology. São Paulo, Brazil: 66-67.

Ribeiro, J.F., \& B.M.T. Walter. 1998. Fitofisionomias do bioma cerrado. In: S.M. Sano, \& S.P. Almeida eds., Cerrado: ambiente e flora. Embrapa Cerrados, Brasília, Brazil: 89-168.

Rodovalho, C.M., A.L. Santos, M.T. Marcolino, A.M. Bonetti, \& M.A.M. Brandeburgo. 2007. Urban ants and transportation of nocosomial bacteria. Neot. Entomol. 36(3): 454-458.

Roncin, E., \& L. Deharveng. 2003. Leptogenys khammouanensis sp. nov. (Hymenoptera: Formicidae). A possible troglobitic species of Laos, with a discussion on cave ants. Zool. Sci. 20: 919-924.

Santana, M.E.V., L.S. Souto, M.A.T. Dantas, C.R. Donato, \& D.M. Oliveira. 2009. Levantamento da fauna de invertebrados cavernícolas na Toca da Raposa, Simão Dias, Sergipe, Brasil. In: XXX Congresso Brasileiro de Espeleologia. Montes Claros, Brazil: CD-ROOM.

Santos, D.B., D.A. Oliveira, \& H.J.S. Menezes. 2002. Registros preliminares de cavidades naturais em Sergipe. In: II Workshop Arqueológico de Xingó. Canindé do São Francisco, Brazil: 117-122.

Silva, M.S., L.F.O. Bernard, \& R.L. Ferreira. 2005. Caracterização sistêmica da Gruta da Lavoura (Matozinhos, MG): aspectos topoclimáticos e biológicos. In: X Congresso Brasileiro de Espeleologia. Campinas, Brazil: CD-ROOM.

Silva, M.S., \& R.L. Ferreira. 2009a. Estrutura das comunidades de invertebrados em cinco cavernas insulares e intertidais na costa brasileira. Espeleo-Temas 20(2): 25-36. 
Silva, M.S., \& R.L. Ferreira. 2009b. Caracterização ecológica de algumas cavernas do Parque Nacional de Ubajara (Ceará) com considerações sobre o turismo nestas cavidades. Rev. Biol. Ciênc. Ter. 9: 59-71.

Solis, D.R., E.G.P. Fox, M.L. Rossi, T.C. Moretti, \& O.C. Bueno. 2010. Description of the immature of workers of the ant Camponotus vittatus (Hymenoptera: Formicidae). Flor. Entomol. 63(2): 265-276.

Tinaut, A., \& F. López. 2001. Ants and caves: sociability and ecological constraints (Hymenoptera, Formicidae). Sociobiol. 37: 651- 659.

Trajano, E. 1987. Fauna cavernícola brasileira: composição e caracterização preliminar. Rev. Bras. Zool. 3(8): 533-561.

Trajano, E., \& P. Gnaspini-Netto. 1991. Composição da fauna cavernícola brasileira com uma análise preliminar da distribuição dos táxons. Rev. Bras. Zool. 7(3): 383-407.

Wilkinson, L. 1998. Systat: the system for statistics. Illinois: SYSTAT Inc. Evaston. 822 pp.

Wilson, E.O. 1962. The trinidad cave ant Erebomyrma (Spelaeomyrmex) urichi (Wheeler), with a comment on cavernicolous ants in general. Psyche 69: 62-72. 
